\title{
Erythropoiesis-stimulating agents for the treatment of chemotherapy- induced anemia: comparisons from real-world clinical experience [Corrigendum]
}

Rodriguez Garzotto A, Heine O, Turner M, et al. J Blood Med.

2014;5:43-48.

The author list should have been:

Analia Rodriguez Garzotto ${ }^{1}$

Susana Cortijo Casacajares ${ }^{1}$

Cristina Pernaut ${ }^{1}$

Gustavo Javier Ruiz Ares ${ }^{1}$

Irene Otero Blas ${ }^{1}$

Oliver Heine ${ }^{2}$

Matthew Turner ${ }^{3}$

Francisco Rebollo Laserna ${ }^{4}$

Hernan Cortes Funes ${ }^{1}$

Andreas Lorenz ${ }^{5}$

${ }^{1}$ Hospital Universitario 12 de Octubre, Ctra Andalucía, Madrid, Spain; ${ }^{2}$ Zentralklinikum Suhl, Suhl, ${ }^{3}$ Sandoz International GmbH, Holzkirchen, Germany; ${ }^{4}$ Sandoz Farmaceutica SA, Madrid, Spain; ${ }^{5}$ Frauenarztpraxis, Hildburghausen, Germany

\section{Publish your work in this journal}

The Journal of Blood Medicine is an international, peer-reviewed, open access, online journal publishing laboratory, experimental and clinical aspects of all topics pertaining to blood based medicine including but not limited to: Transfusion Medicine; Blood collection, Donor issues, Transmittable diseases, and Blood banking logistics; Immunohematology; Artificial and alternative blood based therapeutics; Hematology; Biotechnology/nanotechnology of blood related medicine; Legal aspects of blood medicine; Historical perspectives. The manuscript management system is completely online and includes a very quick and fair peer-review system. Visit http://www.dovepress.com/ testimonials.php to read real quotes from published authors. 